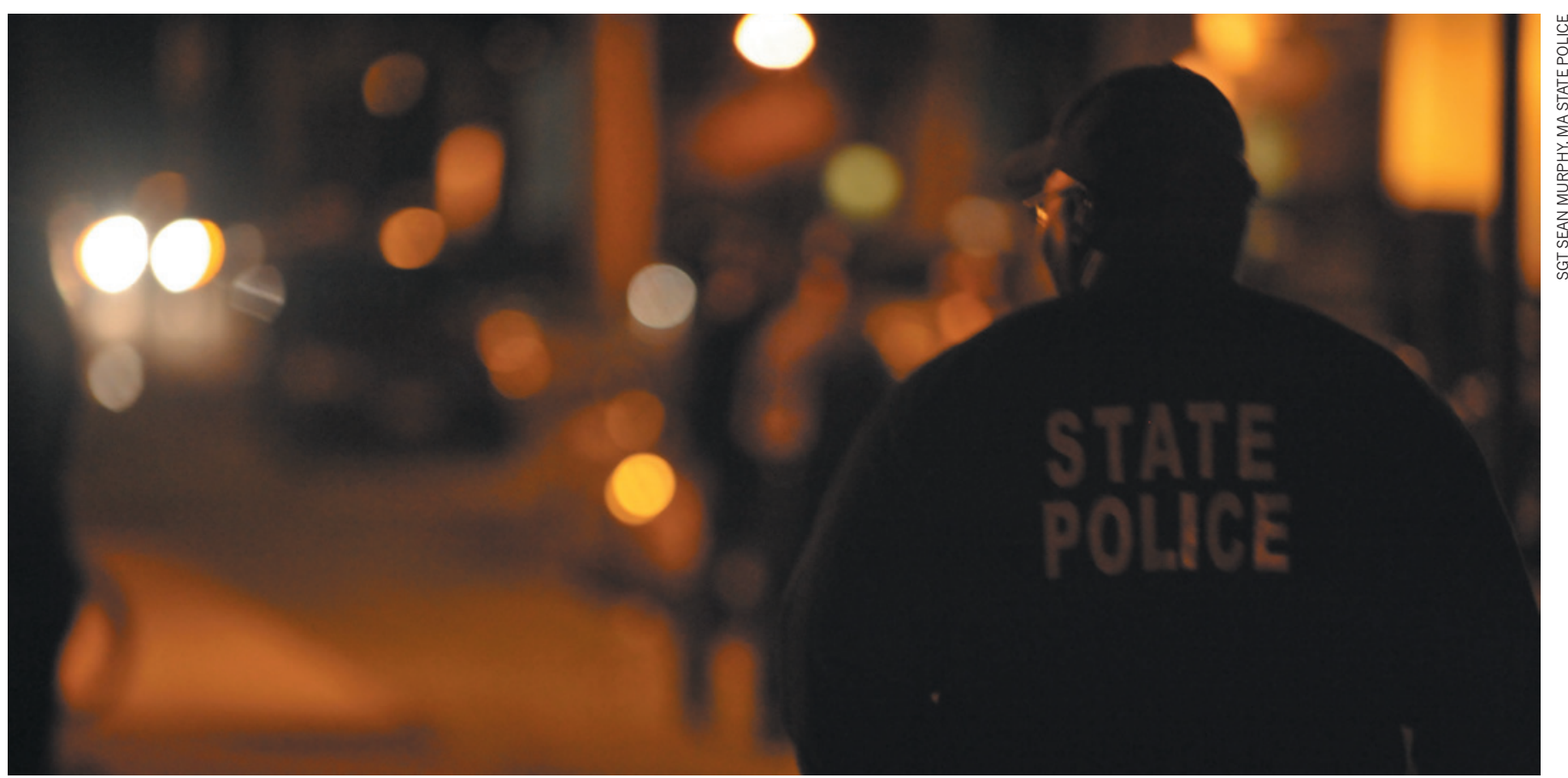

In Springfield, Massachusetts, police draw on military counter-insurgency methods to combat high rates of crime and gang-related violence.

SOCIAL SCIENCE

\title{
A data-driven war on crime
}

\section{Scientific tools inform a unique combination of military tactics and police work.}

\section{BY SHARON WEINBERGER}

A routine midday police patrol through the crime-ridden North End of Springfield, Massachusetts, is interrupted when state troopers spot a teenager riding an unregistered motorcycle with no helmet. Instead of arresting the underage rider, who initially tries to flee, the police speak to him and his father, who is in the crowd that has gathered at the scene. They agree not to charge the boy, for now, if he will tell them who gave him the motorcycle and write a two-page paper about obeying the law.

This approach to law enforcement is part of an initiative called Counter Criminal Continuum $\left(\mathrm{C}^{3}\right)$, which draws on strategies used in US military campaigns against insurgents in Iraq and Afghanistan. The Massachusetts state police launched $\mathrm{C}^{3}$ in 2009 as part of an effort to combat the drugsand gang-related violence that run rampant in parts of Springfield, one of the most dangerous cities in the United States. Now, undergraduate students at Harvard University in Cambridge, Massachusetts, are attempting to bolster the initiative with state-of-the-art data-gathering and analysis of how well these counter-insurgency techniques are working.

Led by Kevin Kit Parker, a biomedical engineer and professor at Harvard, engineering students are collecting data on encounters such as the one with the boy on the motorcycle to look for correlations between policing tactics and crime rates.

Parker, who advises the Pentagon on research projects, has pushed the US defence department to adopt scientific ways of evaluating the effectiveness of counter-insurgency (COIN) in conflict-torn areas. Collecting precise data on factors such as murder rates or income levels in a war zone is almost impossible, however. "There was no way to do science and technology to back up COIN," Parker says. But Springfield, where the police were adopting COIN techniques, offered a realworld laboratory in which to measure their effectiveness.

Parker, a US Army major who had recently returned from Afghanistan, learned of the programme shortly after it began from Michael Cutone, a Massachusetts state trooper and US Green Beret who served in the same National Guard unit as Parker. When Cutone returned from Iraq, he realized that the chaos he saw in Springfield bore a strong resemblance to what he had seen in the northern Iraqi city where he had been deployed.

In 2009, Cutone approached John Barbieri, Springfield's deputy chief of police, with the idea of taking the US counter-insurgency doctrine - which relies on tactics such as collecting intelligence to take down insurgent networks and winning support from the local population - and applying it in Springfield. "I think we can use the Army Special Forces counter-insurgency model and adapt it for law enforcement to combat and attack the gangs and drug dealers," he told Barbieri.

Barbieri decided that it was worth a shot. "If you've got something that works in a remote village," he recalls telling Cutone, "then it's got to work here."

When Parker learned of the effort, he seized on it as a way to test some of the theories that the military was already spending billions of dollars to apply. The Springfield Police Department agreed to work with Parker and his team, and students in Parker's class have routinely been making the two-hour trip to Springfield to gather data on everything from arrests and shootings to education level and rates of infection with sexually transmitted diseases.

Among the elements that the Springfield $\mathrm{C}^{3}$ programme borrows from the military is a data-collection system called Lighthouse, which researchers at the US Naval Postgraduate School in Monterey, California, developed to gather data on insurgents in countries such as Afghanistan. The Springfield police are 
using Lighthouse to collect information on gang members and criminals. Parker's students are trying to use this and other crime-related data to help police to improve their methods. They have created a 'war room', where they are working on social-network analysis and computational social science in an effort to predict where crime may happen.

The students use a variety of methods, including organizing street-level data with Google Maps to plot and photo-document neighbourhoods block by block, and then combining the data with public statistics for crime, demographics and public health. They then use linear-regression techniques to analyse the statistics with the aim of developing computational tools to help police anticipate crime or identify key gang leaders.

In some respects, the project embodies former US defence secretary Robert Gates's vision of strengthening the ties between the Pentagon and academic research. But the ultimate question for Springfield - as for Afghanistan - is whether counter-insurgency (or counter-gang) strategies are effective. Barbieri points to the results in Springfield: a 62\% drop in crime over the first year that $\mathrm{C}^{3}$ was implemented. "I am stunned by how well it works," he says.

On the ground, success is not always obvious. The optimism of the scene in which the

teenager on the motorcycle shakes hands and smiles with state troopers dissolves minutes later, when a police dispatcher reports that the motorcycle was stolen. The teenager now faces possible criminal charges for theft unless he reveals who gave him the bike (which he ultimately does).

And even if $\mathrm{C}^{3}$ works, not everyone believes it should be called counter-insurgency. John Sullivan, a lieutenant with the Los Angeles Sheriff's Department, says that many of these tactics originated with the police, and he worries that calling the approach counter-

\section{Students are developing computational models to analyse and improve police methods.}

insurgency gives the false impression that the police are using military methods. "That convolutes the discussions," he says.

Hugh Gusterson, an anthropologist at George Mason University in Fairfax, Virginia, and a frequent critic of the military's involvement in social-science research, warns that the idea of applying a counter-insurgency approach in domestic law enforcement, however it is labelled, risks casting local communities as hostile populations.

"I'd feel that universities were making more of a positive contribution to society if they worked instead on understanding the connections between crime, social inequality and perceived injustice," he says.

Whether it is police doctrine or military doctrine, studying the effectiveness of counter-insurgency techniques domestically makes sense, says Douglas Ollivant, a senior fellow at the New America Foundation based in Washington DC. Ollivant, who worked as a counterinsurgency adviser to the US military, says that surveys can be carried out and data collected more easily in the United States than in war zones, and could help to answer questions for both the military and the police. "Has COIN been effective?" asks Ollivant. "I think there's a dearth of evidence."

Yet the military has been reluctant to fund efforts like the Springfield-Harvard collaboration. As an adviser to defence agencies, Parker has pitched the idea of a domestic scienceand-technology lab, so far without success. Although what emerges from his work on the Springfield programme may strengthen his case, he acknowledges that a domestic theory of counter-insurgency is a tough sell when many believe it has failed abroad.

"I feel like I'm still trying to find some part of this war I can win," he says, referring to Afghanistan. "Maybe the only thing I can win is building the database and tools for the next insurgency we have to fight." 